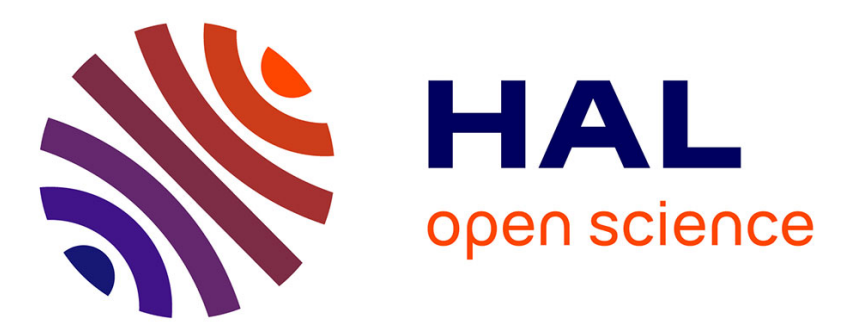

\title{
Immunohistochemical analysis of 1844 human epithelial and hematopoietic tumors and sarcomas for IDH1R132H mutation
}

Felix Sahm, David Capper, Jochen Meyer, Christian Hartmann, Esther Herpel, Mindaugas Andrulis, Gunhild Mechtersheimer, Iver Petersen, Werner Paulus, Andreas von Deimling

\section{To cite this version:}

Felix Sahm, David Capper, Jochen Meyer, Christian Hartmann, Esther Herpel, et al.. Immunohistochemical analysis of 1844 human epithelial and hematopoietic tumors and sarcomas for IDH1R132H mutation. Histopathology, 2011, 58 (7), pp.1167. 10.1111/j.1365-2559.2011.03823.x . hal-00655185

\author{
HAL Id: hal-00655185 \\ https://hal.science/hal-00655185
}

Submitted on 27 Dec 2011

HAL is a multi-disciplinary open access archive for the deposit and dissemination of scientific research documents, whether they are published or not. The documents may come from teaching and research institutions in France or abroad, or from public or private research centers.
L'archive ouverte pluridisciplinaire HAL, est destinée au dépôt et à la diffusion de documents scientifiques de niveau recherche, publiés ou non, émanant des établissements d'enseignement et de recherche français ou étrangers, des laboratoires publics ou privés. 


\section{Histopathology}

\section{Immunohistochemical analysis of 1844 human epithelial and hematopoietic tumors and sarcomas for IDH1R132H mutation}

\begin{tabular}{|c|c|}
\hline Journal: & Histopathology \\
\hline Manuscript ID: & HISTOP-04-10-0206.R1 \\
\hline Wiley - Manuscript type: & Short Report \\
\hline $\begin{array}{r}\text { Date Submitted by the } \\
\text { Author: }\end{array}$ & 14-Jul-2010 \\
\hline Complete List of Authors: & $\begin{array}{l}\text { Sahm, Felix; Institute of Pathology, Department of Neuropathology } \\
\text { Capper, David; Institute of Pathology, Department of } \\
\text { Neuropathology; German Cancer Research Center, Clinical } \\
\text { Cooperation Unit Neuropathology } \\
\text { Meyer, Jochen; German Cancer Research Center, Clinical } \\
\text { Cooperation Unit Neuropathology } \\
\text { Hartmann, Christian; Institute of Pathology, Department of } \\
\text { Neuropathology; German Cancer Research Center, Clinical } \\
\text { Cooperation Unit Neuropathology } \\
\text { Herpel, Esther; Institute of Pathology, Department of General } \\
\text { Pathology; NationalCenter for Tumor Diseases, Tissue Bank } \\
\text { Andrulis, Mindaugas; Institute of Pathology, Department of General } \\
\text { Pathology } \\
\text { Mechtersheimer, Gunhild; Institute of Pathology, Department of } \\
\text { General Pathology } \\
\text { Petersen, Iver; Institute of Pathology } \\
\text { Paulus, Werner; Institute of Neuropathology } \\
\text { von Deimling, Andreas; Institute of Pathology, Department of } \\
\text { Neuropathology; German Cancer Research Center, Clinical } \\
\text { Cooperation Unit Neuropathology }\end{array}$ \\
\hline Keywords: & $\begin{array}{l}\text { IDH1, immunohistochemistry, sarcoma, carcinoma, hematopoietic } \\
\text { tumors }\end{array}$ \\
\hline
\end{tabular}

\section{S ScholaroNE \\ Manuscript Central}


Immunohistochemical analysis of 1844 human epithelial and hematopoietic tumors and sarcomas for IDH1R132H mutation

Felix Sahm ${ }^{1}$, David Capper ${ }^{1,2}$, Jochen Meyer ${ }^{2}$, Christian Hartmann ${ }^{1,2}$, Esther Herpel ${ }^{3,4}$, Mindaugas Andrulis $^{4}$, Gunhild Mechtersheimer ${ }^{4}$, Iver Petersen ${ }^{5}$, Werner Paulus ${ }^{6}$, Andreas von Deimling $^{1,2}$

1. Department of Neuropathology, Institute of Pathology, Ruprecht-Karls-Universität Heidelberg, D-69120 Heidelberg, Germany

2. Clinical Cooperation Unit Neuropathology, German Cancer Research Center, D-69120 Heidelberg, Germany

3. Tissue Bank, NationalCenter for Tumor Diseases Heidelberg, D-69120 Heidelberg, Germany

4. Department of General Pathology, Institute of Pathology, Ruprecht-Karls-Universität Heidelberg, D-69120 Heidelberg, Germany

5. Institute of Pathology, Friedrich-Schiller-Universität Jena, D-07743 Jena, Germany

6. Institute of Neuropathology, University Hospital Münster, D-48129 Münster, Germany

Corresponding author:

Prof. Dr. med. Andreas von Deimling

Department of Neuropathology

Institute of Pathology

Ruprecht-Karls-Universität Heidelberg

D-69120 Heidelberg, Germany

Phone 06221/56-2603/2604

Fax 06221/56-4566

Running title: Mutant IDH1-R132H protein in human tumors 
Sahm et al. 2

\section{Abstract}

Aims: Mutations in the isocitrate dehydrogenase 1 gene have been recently identified to play a key role in diffuse astrocytoma and oligodendroglioma as well as in acute myeloid leukemia. In glioma, IDH1R132H is the most common mutation type, which is associated with younger patient age and a longer patient survival compared to wild type status. Sequencing analyses of carcinomas and lymphomas have detected IDH1 mutations only in a small fraction of cases. In those studies, IDH1R132H was also the most frequent mutation. Aim of the present study was to analyze a comprehensive series of human tumors for IDH1R132H mutation. Methods and results: We stained a total of 1844 formalin-fixed paraffin-embedded tumors including carcinomas, sarcomas and hematopoietic tumors using a mutation specific antibody for $\mathrm{IDH} 1^{\mathrm{R} 132 \mathrm{H}}$. Our positive control series consisted of a collection of diffuse astrocytomas and oligodendrogliomas. No IDH1R132H mutation was found in our series. Conclusions: We conclude that IDH1R132H mutations occur almost exclusively in glioma and acute myeloid leukemia.

\section{Introduction}

Recently, various studies have shown that heterozygous mutations in the isocitrate dehydrogenase 1 (IDH1) gene, encoding a nicotinamide adenine dinucleotide phosphate (NADP+) dependent enzyme, occur frequently in astrocytic and oligodendroglial tumors of WHO grades II and III and in secondary glioblastoma ${ }^{1}$. In a previously published series of 1010 gliomas $71 \%$ of the tumors carried an IDH1 mutation. Of these $93 \%$ were characterized by a base-pair exchange of guanine to adenine (G395A), leading to the substitution of the amino acid arginine by histidine $(\mathrm{R} 132 \mathrm{H})^{2}$. In acute myeloid leukemia (AML), mutations of either IDH1 or isocitrate dehydrogenase 2 (IDH2) were detected in up to $50 \%$ of the tumors ${ }^{3-6}$. In contrast to diffuse glioma, IDH1R132C mutations appear to be more frequent than $I D H 1 R 132 \mathrm{H}$ and very recent data suggest that IDH2 mutations may represent the most frequent mutations in these tumors $^{3,5}$. Sequencing analyses suggested that $I D H 1$ mutations are rare in other tumors $^{7-8}$. The current clinical importance for knowledge on IDH1 mutations in glioma is based on the observation in clinical trials and prospective studies: IDH1 mutation is associated with a significant better prognosis ${ }^{9-10}$.

Biochemical studies revealed that mutant IDH1 protein looses its ability to convert isocitrate to $\alpha$ ketoglutarate ${ }^{11-12}$. However, mutant protein gains a novel function: it catalyzes the reduction of $\alpha$ - 
ketoglutarate to 2-hydroxyglutarate $(2 \mathrm{HG})$ in a NADPH-consuming conversion ${ }^{13}$. Mutation of $I D H 1$ results in an approximately 100 -fold increase of $2 \mathrm{HG}$ in glial tumors ${ }^{13}$. Interestingly, children with a defect in FAD-linked L-2-hydroxyglutarate-dehydrogenase and consecutively increased serum 2HG levels carry an increased risk for brain tumor development ${ }^{14-16}$. The potential cancer forming or promoting function of $2 \mathrm{HG}$ is under investigation. Recently, IDH2 mutations have also been identified to produce $2 \mathrm{HG}^{5}$. Interestingly, novel observations point out that all mutations are localizing to the iscocitrate binding site of the respective enzymes. $I D H 1$ and $I D H 2$ proteins exhibit an extraordinary high level of homology in the amino acid sequence corresponding to this binding site. Thus, increased $2 \mathrm{HG}$ levels may serve as a marker for different $I D H 1$ and $I D H 2$ mutations ${ }^{5-6}$.

Another potentially 2HG-independent mechanism of tumor promotion by $I D H 1$ mutations has been proposed: mutant IDH1 results in a lack of $\alpha$-ketoglutarate $(\alpha-K G)$ which is necessary for maintaining the activity of prolylhydroxylases. Active prolylhydroxylases in turn promote the degradation of HIF-1 $\alpha$. IDH1 mutation mediated reduction of prolylhydroxylases thus results in an increased HIF-1 $\alpha$ activity known for its tumor promoting effects ${ }^{17}$.

Therefore, analysis of tumor specimens for mutated IDH1 protein, especially the most common variant $\mathrm{IDH} 1^{\mathrm{R} 132 \mathrm{H}}$, is important for both clinicians and researchers. The development of a mutation specific antibody suitable also for immunohistochemistry (IHC) on formalin-fixed paraffin-embedded (FFPE) tissue allows efficient screening of large tumor collections for the $\mathrm{R} 132 \mathrm{H}$ mutation ${ }^{18-19}$. IHC allows diagnostic routine analysis and has the advantage of being rapidly performed and allows detection of $\mathrm{IDH} 1^{\mathrm{R} 132 \mathrm{H}}$ protein in its morphological setting. In this study, we investigated 1844 tumors for presence of IDH1 $1^{\mathrm{R} 132 \mathrm{H}}$ by IHC. 
Sahm et al. 4

\section{Material and Methods}

\section{Tissue specimens}

FFPE tissues were provided by the Tissue Bank, NationalCenter for Tumor Diseases Heidelberg (NCT) and the Department of General Pathology, Institute of Pathology Heidelberg, the Department of Pathology, University Hospital of Jena and the Institute of Neuropathology, University Hospital, Münster. The control series of glioma specimens ${ }^{18-19}$ was obtained from the Department of Neuropathology, Institute of Pathology, University Hospital Heidelberg. All tumors with exception of the 23 specimens of prostate carcinoma and in part the glioma control group were sampled on tissue micro arrays (TMA). Tumor entities and number of respective samples are given in table 1.

\section{Immunohistochemistry}

For immunohistochemstry we used the previously described antibody against mutant $\mathrm{IDH} 1^{\mathrm{R} 132 \mathrm{H}}$ protein, clone $\mathrm{H} 09$ (Dianova, Hamburg, Germany) ${ }^{18-19}$. Sections cut to $3 \mu \mathrm{m}$ were incubated and processed with clone $\mathrm{H} 09$ on a Ventana BenchMark XT® immunostainer (Ventana Medical Systems, Tucson, AZ, USA). The Ventana staining procedure included pretreatment with cell conditioner $2(\mathrm{pH} 6)$ for $60 \mathrm{~min}$, followed by incubation $\mathrm{H} 09$ hybridoma supernatant at $37^{\circ} \mathrm{C}$ for $32 \mathrm{~min}$. Incubation was followed by Ventana standard signal amplification, UltraWash, counterstaining with one drop of hematoxylin for $4 \mathrm{~min}$ and one drop of bluing reagent for $4 \mathrm{~min}$. For visualization, ultraView ${ }^{\mathrm{TM} U n i v e r s a l}$ DAB Detection Kit (Ventana Medical Systems) was used. Binding of antibody was scored as previously described ${ }^{19}$.

\section{PCR amplification and direct sequencing}

DNA was extracted from FFPE tissue of 7 cases with ambiguous binding pattern using standard protocols. A fragment spanning the catalytic domain of IDH1 including codon 132 was amplified using 60ng each of the primer IDH1f TGATGAGAAGAGGGTTGAGGA and the primer IDH1r ATCCCCATAAGCATGACGAC. Primer design was based on accession number NM_005896. For PCR, 20ng of DNA and 2x PCR Master Mix (Promega, Madison, WI, USA) were employed. PCR was performed in a total volume of $15 \mu \mathrm{l}$, and included initial denaturation at $180^{\circ} \mathrm{C}$ for $30 \mathrm{~s}$, followed by 35 cycles with denaturation at $95^{\circ} \mathrm{C}$ for $30 \mathrm{~s}$, annealing at $56^{\circ} \mathrm{C}$ for 40 s and extension at $72^{\circ} \mathrm{C}$ for $50 \mathrm{~s}$. Two microliters of the amplification product was submitted to sequencing using the BigDye $\AA$ 
Terminator v3.1 Sequencing Kit (Applied Biosystems, Foster City, CA, USA). Twenty-five cycles were performed employing $12 \mathrm{ng}$ of the sense primer IDH1f TGATGAGAAGAGGGTTGAGGA, with denaturation at $95^{\circ} \mathrm{C}$ for $30 \mathrm{~s}$, annealing at $56^{\circ} \mathrm{C}$ for $15 \mathrm{~s}$ and extension at $60^{\circ} \mathrm{C}$ for $240 \mathrm{~s}$. Sequences were determined using the semiautomated sequencer (ABIB 3100 Genetic Analyzer, Applied Biosystems) and the Sequence Pilot version 3.1 ${ }^{\mathrm{TM}}$ (JSI-Medisys, Kippenheim, Germany) software. 
Sahm et al. 6

\section{Results}

We analyzed 1844 tumors for mutant IDH1 ${ }^{\mathrm{R} 132 \mathrm{H}}$ protein by IHC using the mouse monoclonal antibody H09. The group of epithelial tumors consisted of 23 prostate carcinomas, 326 colon carcinomas, 110 renal cell carcinomas (including clear-cell, papillary and chromophobe carcinomas), 143 non-small-cell lung carcinomas (including squamous cell and adenocarcinomas), 258 breast carcinomas (including invasive ductal and lobular subtypes), 4 thyroid carcinomas, 7 nasopharyngeal squamous cell carcinomas, 7 upper gastrointestinal carcinomas, 132 pancreatic carcinomas, 148 neuroendocrine gastrointestinal tumors and 98 carcinoid tumors. In the set of choroid plexus tumors, we analyzed 15 choroid plexus papillomas, 1 atypical choroid plexus papilloma and 3 choroid plexus carcinomas. Among 1275 epithelial tumors, 1268 were clearly negative and 7 yielded an ambiguous result. These 7 tumors were analyzed by direct sequencing which did not detect an IDH1 mutation in codon 132 . Thus, none of the 1275 epithelial tumors contained mutant IDH $1^{\mathrm{R} 132 \mathrm{H}}$ protein. We further screened 364 different sarcomas, including 137 angiosarcomas, 35 leiomyosarcomas, 36 synovial sarcomas, 97 liposarcomas, 23 myxofibrosarcomas and 36 malignant fibrous histiocytomas. No IDH1R132H mutation was detected in sarcomas. The analysis of 179 lymphomas (including 34 follicular lymohomas, 41 diffuse large B cell lymphomas, 25 primary mediastinal B cell lymphomas, 17 mantle cell lymphomas, 16 marginal zone lymphomas and 46 Hodgkin's lymphomas) and 26 extramedullary plasmacytomas yielded also no IDH1R132H mutation.

In the control series of 116 diffuse gliomas, the $\mathrm{IDH} 1^{\mathrm{R} 132 \mathrm{H}}$ protein was found in 99/116 (85\%) cases. 


\section{Discussion}

Our series included 1275 epithelial tumors, 364 sarcomas, 205 hematopoietic tumors and a control series of gliomas. In none of the 1275 epithelial tumors $I D H 1^{\mathrm{R} 132 \mathrm{H}}$ protein was detected. The very close association of $\mathrm{IDH} 1^{\mathrm{R} 132 \mathrm{H}}$ protein with $\mathrm{IDH} 1 \mathrm{R} 132 \mathrm{H}$ mutation has been demonstrated previously ${ }^{18-}$ ${ }^{19}$. Our data set was controlled by the inclusion of 116 diffuse gliomas exhibiting the $\mathrm{IDH} 1^{\mathrm{R} 132 \mathrm{H}}$ protein in 99/116 (85\%) cases. Clone H09 is highly specific for tumors. No binding of H09 has been detected in reactive glial and non-glial tissues ${ }^{20}$. Of note, because all IDH1 mutations are heterozygous, wild type IDH1 protein is expressed in all: tumor tissues with mutation, tumor tissues without mutation, normal tissue and reactive cells. Thus, the IDH1R132H mutation appears to be absent or very rare in epithelial tumors. IDH1 mutations in carcinoma have been analyzed in previous studies. Our series did not provide evidence for IDH1R132H mutations in colon, breast, kidney, lung, pancreatic, thyroid, upper gastrointestinal, nasopharyngeal and 3 choroid plexus carcinomas and in 15 plexus papillomas. In fact, six colon and 1 kidney carcinomas yielded ambiguous binding pattern, however, both, reanalysis on full tissue sections and DNA sequencing revealed wild type status in all seven instances. In the previous series, IDH1R132H mutations have been detected in a very low fraction of prostate, colon and thyroid carcinomas. In a series by Kang this alteration has been detected in 2/75 cases of prostate carcinoma ${ }^{8}$. Our series included only 23 prostate carcinoma specimens all of which were negative for IDH1R132H protein, therefore well in line with the published data. In a whole cancer genome sequencing approach, Sjöblom et al detected IDH1R132H mutation in $1 / 11$ colon carcinoma $^{21-22}$. The present series including 326 colon carcinomas did not exhibit a single case with IDH1R132H protein. Our findings are matched by absence of IDH1 mutation in 128 and 97 colon carcinomas in the series by Bleeker et al. and Kang et al., respectively ${ }^{7-8}$. A very recent study detected $3 \mathrm{IDH} 1$ mutations in 38 thyroid cancers, however the mutations detected did not affect codon 132 of $I D H 1^{23}$. We did not find either IDH1R132H mutation in the 4 thyroid carcinomas from our series.

Data on IDH1 status in sarcoma was not available so far. Our study contains 364 different sarcomas, including angiosarcoma, leiomyosarcoma, synovial sarcoma, liposarcoma, myxofibrosarcoma and malignant fibrous histiocytoma. IHC for IDH1 ${ }^{\mathrm{R} 132 \mathrm{H}}$ protein did not reveal any mutation in sarcomas. All together, our data confirm on protein level the absence or extreme rarity of IDH1R132H mutations in epithelial and sarcomatous tumors.

Acute myeloid leukemia (AML) so far is the only non CNS tumor described with a substantial number of $I D H 1$ mutations. We, therefore, extended our series to include additional hematopoietic neoplasms. 
Sahm et al. 8

We did not detect IDH1 ${ }^{\mathrm{R} 132 \mathrm{H}}$ protein in 179 lymphomas of different subtypes and in 26 plasmacytomas. We could demonstrate the ability of clone $\mathrm{H} 09$ to bind to hematopoietic lesions with IDH1R132H mutation in a preceding study demonstrating mutant protein in 3 of 71 patients with myelodysplastic syndrome $^{24}$. Thus our data complements a previous study by Kang et al. with a focus on various subtypes of leukemias in which 1 mutation among 186 leukemias has been reported $^{8}$. It appears that IDH1R132H mutations are rare or absent in hematopoietic tumors apart from AML and precursor lesions thereof.

The availability of a mutation specific antibody for detection of mutant $\mathrm{IDH} 1^{\mathrm{R} 132 \mathrm{H}}$ protein is of great value in the analysis of tumor entities carrying those alterations. It allows application of standard protocols for IHC and in comparison to DNA extraction followed by sequencing currently is more rapid and inexpensive. We performed our analyses on a semi-automated staining system (Ventana BenchMark XT® immunostainer, Ventana Medical Systems, Tucson, AZ, USA), however, antibody clone H09 has been successfully used with very different protocols (personal communication A. von Deimling). Another considerable advantage is the ability of $\mathrm{IHC}$ to detect small groups of or even single tumor cells, whereas DNA analysis may be compromised by presence of non tumorous cells contributing wild type DNA. TMA analysis with clone H09 is very rewarding because so far, all tumors examined appeared to carry the mutation in every tumor cell and all these cells expressed IDH $1^{\mathrm{R} 132 \mathrm{H}}$ protein allowing efficient detection. However, IDH1R132H is predominantly seen in diffuse gliomas whereas it is virtually absent in carcinoma and sarcoma. While the diagnostic potential for clone H09 is evident for brain tumors, it appears to be irrelevant for most of the extracranial tumor entities. The value for such analysis in AML needs to be tested. 


\section{Acknowledgements}

We wish to thank our colleagues Stephan Macher-Göppinger, Beate K Straub and Arne Warth for material support and Diana Jäger for skilful technical assistance.

This work was supported by the Bundesministerium für Bildung und Forschung (BMBF-01ES0730 and 01GS0883). 


\section{References}

1. Balss J, Meyer J, Mueller W, Korshunov A, Hartmann C, von Deimling A. Analysis of the IDH1 codon 132 mutation in brain tumors. Acta Neuropathol 2008;116;597-602.

2. Hartmann $\mathrm{C}$, Meyer $\mathrm{J}$, Balss $\mathrm{J}$ et al. Type and frequency of IDH1 and IDH2 mutations are related to astrocytic and oligodendroglial differentiation and age: a study of 1,010 diffuse gliomas. Acta Neuropathol 2009;118;469-474.

3. Mardis ER, Ding L, Dooling DJ et al. Recurring mutations found by sequencing an acute myeloid leukemia genome. N Engl J Med 2009;361;1058-1066.

4. Chou WC, Hou HA, Chen CY et al. Distinct clinical and biologic characteristics in adult acute myeloid leukemia bearing the isocitrate dehydrogenase 1 mutation. Blood 2010;115;27492754.

5. Ward PS, Patel J, Wise DR et al. The Common Feature of Leukemia-Associated IDH1 and IDH2 Mutations Is a Neomorphic Enzyme Activity Converting alpha-Ketoglutarate to 2Hydroxyglutarate. Cancer Cell 2010;17;225-234.

6. Gross S, Cairns RA, Minden MD et al. Cancer-associated metabolite 2-hydroxyglutarate accumulates in acute myelogenous leukemia with isocitrate dehydrogenase 1 and 2 mutations. J Exp Med 2010;207;339-344.

7. Bleeker FE, Lamba S, Leenstra S et al. IDH1 mutations at residue p.R132 (IDH1(R132)) occur frequently in high-grade gliomas but not in other solid tumors. Hum Mutat 2009;30;7-11.

8. Kang MR, Kim MS, Oh JE et al. Mutational analysis of IDH1 codon 132 in glioblastomas and other common cancers. Int J Cancer 2009;125;353-355.

9. Parsons DW, Jones $\mathrm{S}$, Zhang $\mathrm{X}$ et al. An integrated genomic analysis of human glioblastoma multiforme. Science 2008;321;1807-1812.

10. Wick W, Hartmann C, Engel C et al. NOA-04 randomized phase III trial of sequential radiochemotherapy of anaplastic glioma with procarbazine, lomustine, and vincristine or temozolomide. J Clin Oncol 2009;27;5874-5880.

11. Yan H, Parsons DW, Jin G et al. IDH1 and IDH2 mutations in gliomas. N Engl J Med 2009;360;765-773.

12. Ichimura K, Pearson DM, Kocialkowski S et al. IDH1 mutations are present in the majority of common adult gliomas but rare in primary glioblastomas. Neuro Oncol 2009;11;341-347.

13. Dang L, White DW, Gross S et al. Cancer-associated IDH1 mutations produce 2hydroxyglutarate. Nature 2009;462;739-744.

14. Rzem R, Veiga-da-Cunha M, Noel $\mathrm{G}$ et al. A gene encoding a putative FAD-dependent L-2hydroxyglutarate dehydrogenase is mutated in L-2-hydroxyglutaric aciduria. Proc Natl Acad Sci U S A 2004;101;16849-16854.

15. Moroni I, Bugiani M, D'Incerti L et al. L-2-hydroxyglutaric aciduria and brain malignant tumors: a predisposing condition? Neurology 2004;62;1882-1884.

16. Topcu M, Jobard F, Halliez S et al. L-2-Hydroxyglutaric aciduria: identification of a mutant gene C14orf160, localized on chromosome 14q22.1. Hum Mol Genet 2004;13;2803-2811.

17. Zhao S, Lin Y, Xu W et al. Glioma-derived mutations in IDH1 dominantly inhibit IDH1 catalytic activity and induce HIF-1alpha. Science 2009;324;261-265.

18. Capper D, Zentgraf H, Balss J, Hartmann C, von Deimling A. Monoclonal antibody specific for IDH1 R132H mutation. Acta Neuropathol 2009;118;599-601.

19. Capper D, Weissert S, Balss J et al. Characterization of R132H mutation-specific IDH1 antibody binding in brain tumors. Brain Pathol 2010;20;245-254.

20. Capper D, Sahm F, Hartmann C. Application of mutant IDH1 antibody to differentiate diffuse glioma from non-neoplastic central nervous system lesions and therapy induced changes. $A m$ J Surg Pathol 2010. in press

21. Wood LD, Parsons DW, Jones $S$ et al. The genomic landscapes of human breast and colorectal cancers. Science 2007;318;1108-1113.

22. Sjoblom T, Jones S, Wood LD et al. The consensus coding sequences of human breast and colorectal cancers. Science 2006;314;268-274.

23. Murugan AK, Bojdani E, Xing M. Identification and functional characterization of isocitrate dehydrogenase 1 (IDH1) mutations in thyroid cancer. Biochem Biophys Res Commun 2010;393;555-559.

24. Andrulis M, Capper D, Luft T, Hartmann C, Zentgraf H, von Deimling A. Detection of isocitrate dehydrogenase 1 mutation $\mathrm{R} 132 \mathrm{H}$ in myelodysplastic syndrome by mutation-specific antibody and direct sequencing. Leuk Res 2010;34;1091-1093. 


\section{Legends to table and figure}

Table 1: Immunohistochemical results of IDH1 ${ }^{\mathrm{R} 132 \mathrm{H}}$ specific antibody in epithelial, sarcomatous and hematopoietic tumors, glioma control group. *previously published

Figure 1: Top row shows negative staining with $\mathrm{IDH} 1^{\mathrm{R} 132 \mathrm{H}}$ specific antibody in colon carcinoma $(\mathrm{a}, \mathrm{c})$, choroid plexus carcinoma (b), and breast carcinoma (d). Lower row shows diffuse glioma control group in tumors with IDH1R132H mutation (e,g,h) and IDH1 wild type (f) 


\begin{tabular}{|c|c|c|}
\hline Entity & positiv & total \\
\hline Prostate carcinoma & 0 & 23 \\
\hline Colon carcinoma & 0 & 326 \\
\hline Renal cell carcinoma & 0 & 110 \\
\hline clear-cell & 0 & 67 \\
\hline papillary & 0 & 4 \\
\hline chromophobe & 0 & 12 \\
\hline others & 0 & 27 \\
\hline Non-small-cell lung carcinoma & 0 & 143 \\
\hline Squamous cell carcinoma & 0 & 59 \\
\hline Adenocarcinoma & 0 & 62 \\
\hline Others & 0 & 22 \\
\hline Breast carcinoma & 0 & 258 \\
\hline invasive ductal & 0 & 167 \\
\hline invasive lobular & 0 & 43 \\
\hline others & 0 & 48 \\
\hline Thyroid carcinoma & 0 & 4 \\
\hline Nasopharyngeal squamous cell carcinoma & 0 & 7 \\
\hline Upper gastrointestinal carcinoma & 0 & 7 \\
\hline Pancreatic carcinoma & 0 & 132 \\
\hline Neuroendocrine gastrointestinal tumors & 0 & 148 \\
\hline Carcinoid & 0 & 98 \\
\hline Choroid plexus papilloma & 0 & 15 \\
\hline Atypical choroid plexus papilloma & 0 & 1 \\
\hline Choroid plexus carcinoma & 0 & 3 \\
\hline Angiosarcoma & 0 & 137 \\
\hline Leiomyosarcoma & 0 & 35 \\
\hline Synovial sarcoma & 0 & 36 \\
\hline Myxoid liposarcoma & 0 & 36 \\
\hline Dedifferentiated liposarcoma & 0 & 48 \\
\hline Pleomorphic liposarcoma & 0 & 13 \\
\hline Myxofibrosarcoma & 0 & 23 \\
\hline Malignant fibrous histiocytoma & 0 & 36 \\
\hline Extramedullary plasmacytoma & 0 & 26 \\
\hline Follicular lymphoma & 0 & 34 \\
\hline Diffuse large B cell lymphoma & 0 & 41 \\
\hline Primary mediastinal B cell lymphoma & 0 & 25 \\
\hline Mantle cell lymphoma & 0 & 17 \\
\hline Marginal zone lymphoma & 0 & 16 \\
\hline Hodgkin's lymphoma & 0 & 46 \\
\hline Diffuse astrocytoma WHO grade II * & 44 & 53 \\
\hline Anaplastic astrocytoma WHO grade III * & 25 & 31 \\
\hline Oligodendroglioma WHO grade II * & 16 & 16 \\
\hline Anaplastic oligodendroglioma WHO grade III * & 14 & 16 \\
\hline
\end{tabular}


Figure 1
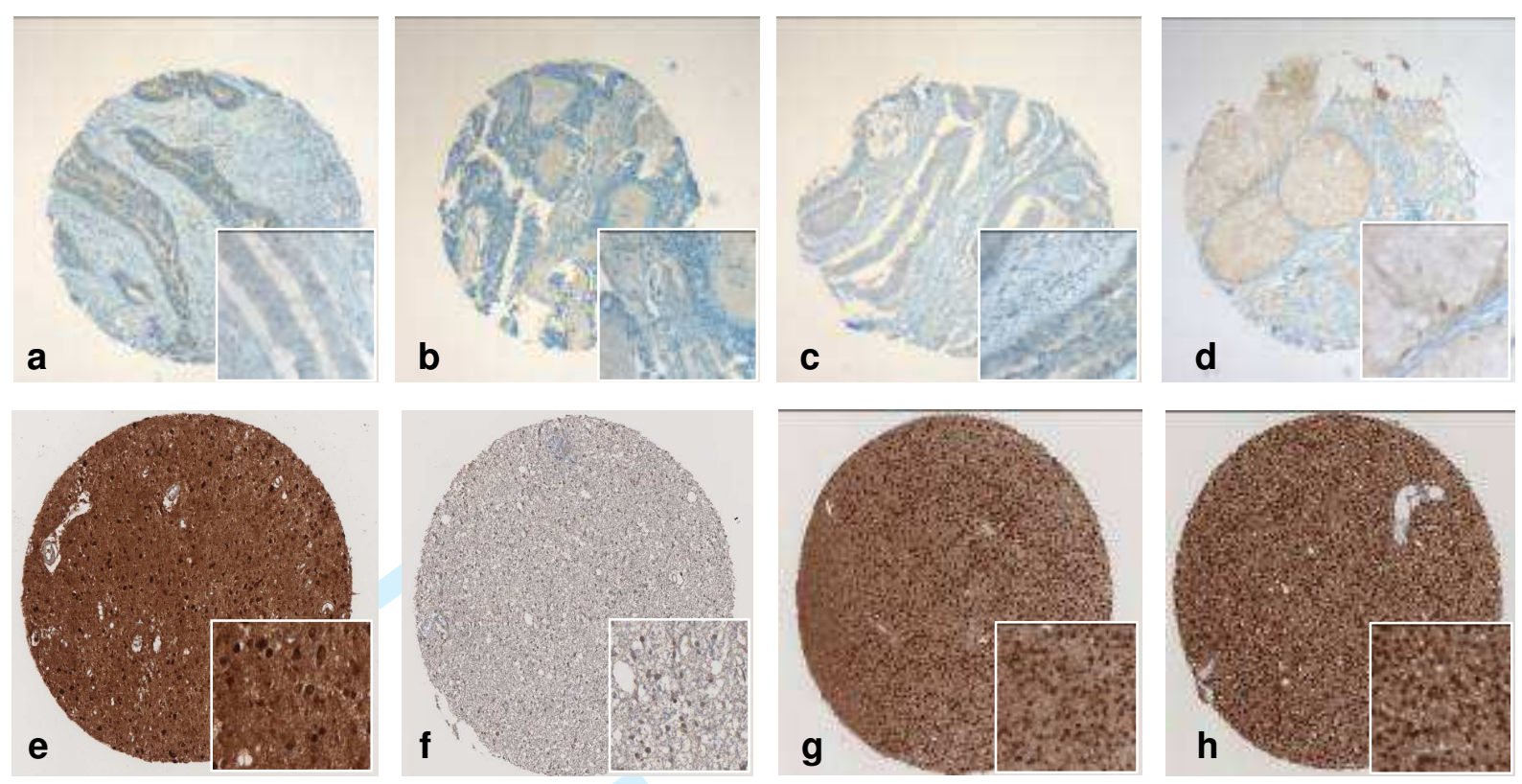